\title{
List of Names \\ (P. Cairo Museum SR 3049/95 Verso)
}

\author{
Sayed Omar \\ Faculty of Arts \\ Ain Shams University
}

A dark brown papyrus damaged in the right upper side. It measures $10 \mathrm{~cm}$ width and $18.2 \mathrm{~cm}$ height, mutilated and suffers from some holes. The upper, lower and left margins are kept. The document contains eighteen lines, the ink in the beginning of the first line and the end of the fifth line is so abraded that makes the reading difficult. The letters have been written separately across the fibers on the verso side in a professional semi cursive hand.

This text is one of a papyrus collection found in Fayum province by the farmers and brought to the Egyptian Museum in Cairo in 26 June 1927. The majority of these papyri are from Theadelphia village (Harit) and a very few from Karanis village (Kom Oshim).

This text is a list of sixteen men, most probably of persons available for service. One of those men, Heron son of Aphrodisios (line 6), has been mentioned in Soterichos archive, who lived in Theadelphia in the second half of the $1^{\text {st }}$ and the beginning of the $2^{\text {nd }}$ century ${ }^{(1)}$. He was a lessor of a palm-grove together with another person, and gave the lessee Soterichos a receipt for rent ${ }^{(2)}$. Heron the son of Aphrdisios was in the year 88 $\mathrm{AD}$ about forty years old ${ }^{(3)}$, therefore one may assume that this list returns to the same place and date of Soterichos archive. 
The names Heras (line 9) and Tesenouphis (line 11) are names for men or women ${ }^{(4)}$ (see note lines 9,11). All the other fourteen names of the list are Masculine, therefore these names should be for men and not for women. The craft of Tenesouphis, as a cobbler ( $\eta \pi \eta \tau \eta \zeta)$ is mentioned instead of his father's name (see note line 11).

The name Sambas in line 13 is mentioned as son Tapsois, which is a feminine name ${ }^{(5)}$. Sambas was fatherless ( $\left.\alpha \pi \alpha \tau \omega \rho\right)$ and this name is his mother's name. More than 800 attestations of fatherlessness are known in papyri, from the beginning of the first to the late third century. Many of the apatores were children of roman soldiers, but not all, since the term is attested a few times after $197 \mathrm{AD}$, when the ban on the roman soldiers' marriage is lifted. The term $\alpha \pi \alpha \tau \omega \rho$ is attested in Arsinoite and many other nomes, while $\chi \rho \eta \mu \alpha \tau \imath \zeta \omega \nu \mu \eta \tau p o s$ "officially described as the son of (name of mother)" was found in Oxyrhynchite nome ${ }^{(6)}$. The term $\alpha \pi \alpha \tau \omega \rho$ is usually noted before the mother's name, but in some cases, as here, the term is not mentioned (see note line 13).

\section{Text:}

$\tau(0) \alpha v \tau(0) \tau \alpha \beta \lambda \imath(0 \nu)$

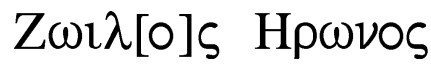

I $\alpha \sigma \omega \nu$ X $\alpha 1 p \eta \mu$ ovos

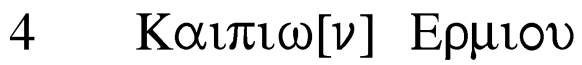

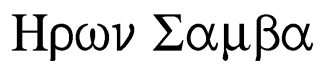

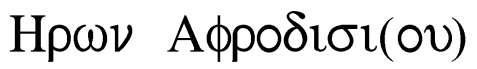

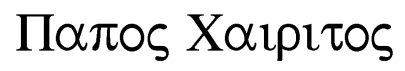

$8 \quad[\Sigma] \cup \rho \circ[\varsigma] \mathrm{A} \pi \circ \lambda[\lambda] \omega \nu(\circ \varsigma)$

$\mathrm{H} \rho \alpha \varsigma \mathrm{X} \rho v \sigma \alpha \phi[10] v$ 


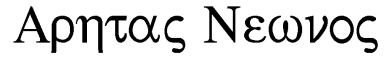

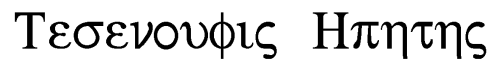

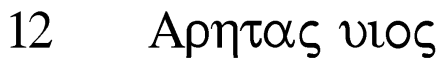

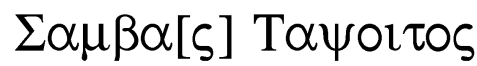

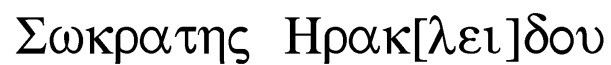

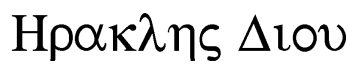

$16 \Pi \varepsilon \theta \varepsilon v \varsigma \Delta 10 v$

$\mathrm{M} v \sigma \theta \alpha \rho[\alpha \varsigma] \Pi \tau 0 \lambda \varepsilon \mu \alpha[10] v$

$\gamma(\mathrm{lvO \nu \tau \alpha l)}$ is

\section{Translation:}

The same list

Zoilos, son of Heron

Iason, son of Chairemon

Kaipion, son of Hermias

Heron, son of Sambas

Heron, son of Aphrodisios

Papos, son of Chairis

Syros, son of Apollon

Heras, son of Chrysaphios

Aretas, son of Neon.

Tesenouphis, son of Epetes (the cobbler)

Aretas, his son

Sambas, son of Tapsois

Sokrates, son of Heraklides

Herakles, son of Dios

Petheus, son of Dios

Mystharas, son of Ptolemaios

(The total) 16

Commentary : 
$=$ List of Names (P. Cairo Museum SR 3049/95 Verso)

$1 \tau \alpha \beta \lambda l(O \nu)$ the reading is doubtful. The letters $\lambda l$ are written together as one letter and could be $\nu$, therefore one may $\operatorname{read} \tau \alpha \beta(\lambda 10) \nu$

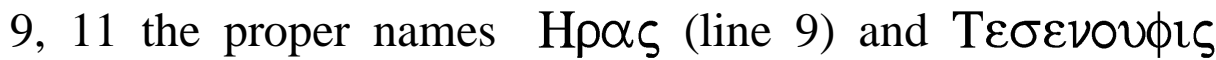
(line 11) can be masculine or feminine, see introduction. This kind of Greek names is very rare. The following proper names are also from the same kind:

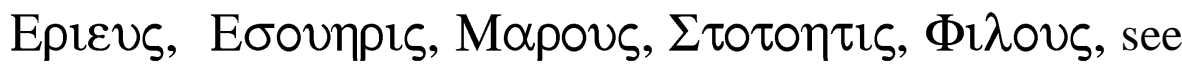
Preisigke, Namenbuch s. v.; Foraboschi, Onomasticon, s. v.

$\mathrm{H} \pi \eta \tau \eta \varsigma$ is used as proper name and could be written also $\eta \pi \eta \tau \eta \varsigma$ "cobbler" as the craft of Tesenouphis, cf. P.Tebt.III 1076, 22 (List of names, late second century BC).

13 Tayors is a woman's name, see the introduction. The mother's name of the fatherless persons is usually preceded by $\alpha \pi \alpha \tau \omega \rho \mu \eta \tau \rho \circ \zeta$, and sometimes by $\alpha \pi \alpha \tau \omega \rho$, or $\mu \eta \tau \rho \circ \varsigma$ only. In rare conditions it is mentioned directly without any term before the mother's name, as here, cf. P.Amh.II 98, $6=$ C.Pap.Jud.III 468, 6 (Abstract of contracts from Hermopolis,

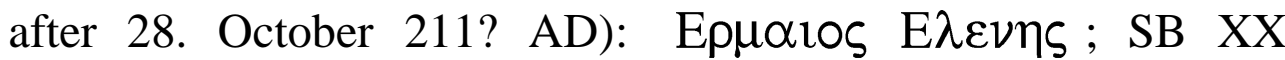
14076,5 (Account from Oxyrhynchus, $5^{\text {th }}$ or $6^{\text {th }}$ century AD): $\delta(1 \alpha) \Pi \alpha \mu \circ v \theta i o v$ E $\lambda \varepsilon v \eta s$. There is also another way to write the mother's name of the fatherless persons as in P.Athen. 43, 3

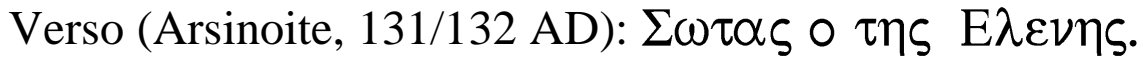

$17 \gamma($ lvOV $\tau \alpha \mathrm{l}) \mathrm{is}$ : The total of the proper names is sometimes counted at the end of the list. This list contains of sixteen men. 


\section{Notas}

1. Sayed Omar, Das Archiv des Soterichos, Westdeutscher Verlag , Opladen Germany 1979.

2. P.Soter. 6 (4. November 88 AD), Theadelphia.

3. Ibid line 7.

4. See Preisigke, Namenbuch s. v.; Foraboschi, Onomasticon, s.v.

5. See ibid.

6. See Myrto Malouta, The Terminology of Fatherlessness in Roman Egypt, Proceedings of the $24^{\text {th }}$ International Congress of Papyrology, Helsinki Finland 2007, Vol.II pp.615ff.

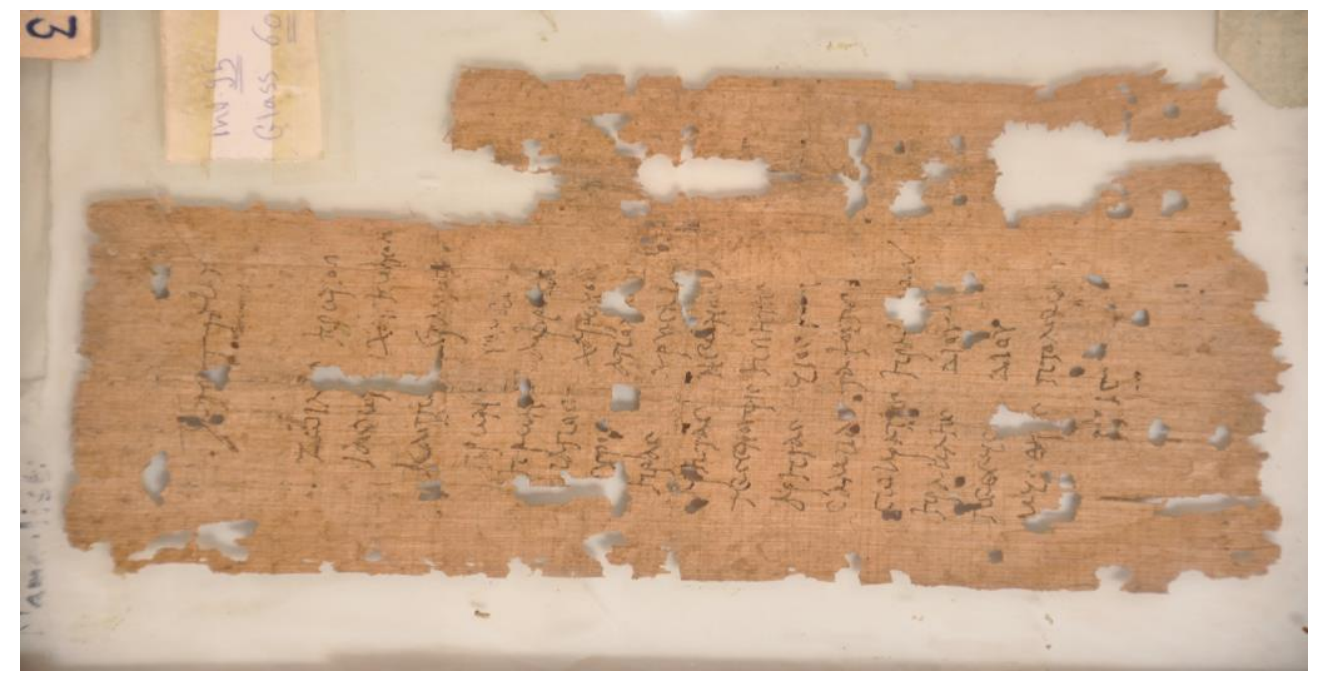


$=$ List of Names (P. Cairo Museum SR 3049/95 Verso)

$$
\begin{aligned}
& \text { قائمة أسماء } \\
& \text { (المتحف المصرى -سجل خاص ه 9/ } 9 \text { ؛ . r) }
\end{aligned}
$$

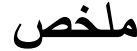

البحث عبارة عن دراسة وتحقيق ونشر وثثية بردية لم تتشر من قبل، كان قد تم العثور عليها

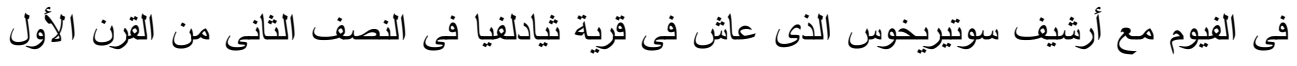
وبداية القرن الثانى الميلادى. الوثيقة عبارة عن قائمة أسماء تتكون من ستة عشر رجلا، ربما من

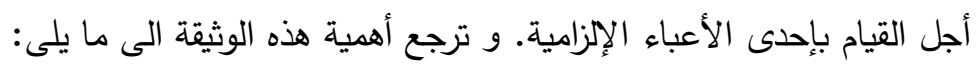

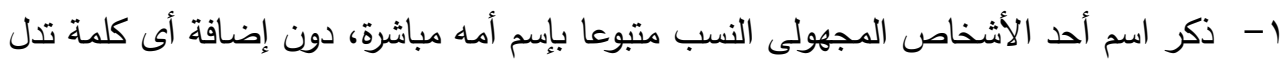

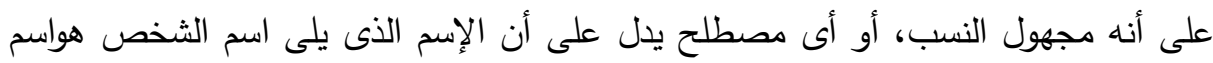

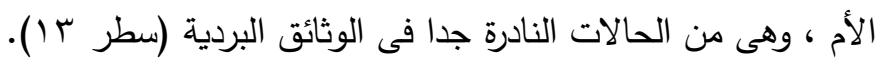

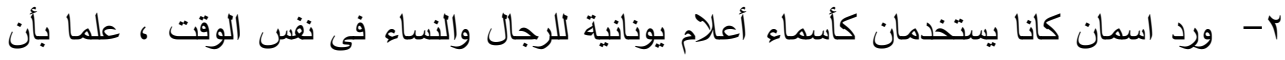
اطلاق نفس الأسم على الرجل و المرأة فى مصر فى العصرين البطلمى والرومانى كان نادرا

$$
\text { جدا (سطر } 9 \text { ، (1) ) (1). }
$$

r- إستخدام الحرفة كلقب بدلا من اسم الأب: تيسينوفيس الإسكافى (سطر (1). 